\title{
Investors Perceptions \& Corporate Announcements for Mumbai \& Hyderabad
}

\author{
Lakshmi Rawat
}

\begin{abstract}
Markets and investor perceptions on the movements of the markets, with specific reference to the equity stock prices of Nifty 50 Index, are being investigated through the present paper. Most of the theories assert the assumption of rational investor and behavioral attributes of investors in the process of price prediction. Through the present paper, an inquiry is made on the relationship between the investor perceptions about the importance or impact of various corporate announcements on the equity stock prices through the primary data. Mumbai has been perceived to be the Mecca of stock investors. Hence the sample have been selected from two different locations Mumbai and Hyderabad to compare and comprehend on the investor perceptions.
\end{abstract}

Keywords: Corporate announcements, Investor perceptions, Retail investor, Stock prices.

\section{INTRODUCTION}

When it comes to investing in stocks directly, there is a need to understand various facets of the firm which may directly or indirectly influence its stock prices. There has been sufficient research to understand the behavior of stock prices in relation to various firm related factors more specifically the corporate actions and other accounting information, but no consensus has been arrived according to literature.

(Groves, 2008) An event initiated by the company which affects the value of its shares is a corporate event. These actions are set out by the articles of association, and the impact is noticed on the financial position of the firm. The dividend on stocks is a proportion of the profits that are distributed by the company to its shareholders. It is declared as a dividend per share depending upon the management board's decision. Dividends are paid out of the retained earnings of the company; therefore when a cash dividend is announced it directly reduces the retained earnings of the firm to that extent. When

a company pays the dividend, the company's values reduce to the extent of the total payout. Therefore it is believed that the stock prices may also reduce to the same extent. But in practice, this may not be true always, as stock prices are affected by several other factors too, and are dependent on the future forecast of the firm's profits to a large extent. These dividends may be paid as cash dividends or as Bonus shares.

A bonus issue is an extra free share distributed to the existing shareholders of the company without any additional

Revised Manuscript Received on July 22, 2019.

Dr. Lakshmi Rawat, Vishwa Vishwani Institute of Systems and Management, lakshmi_rwt@yahoo.co.in, Mob. 9985806177. cost, a number of bonus shares depend upon the number of shared already owned by the investor. Thus, the issue of bonus shares increases the number of shares owned by the company, without any change in the ratio of shares held by each shareholder. This leads to an increase in the volume of the stock. There is also an increase in the share capital of the firm but a decrease in reserves, as bonus shares are issued by converting the reserves of the company into share capital.

From the investors perspective, the investment in the firm does not change immediately, but post announcement the share price per share may reduce to the extent of bonus issued. The Earnings per Share will also change the post issue as the earnings have to be divided by the new increased number of shares. A bonus issue is perceived to be a symbol of the company's good health and may bring in capital gains in the long run with an increase in stock prices.

Stock Split: It is an announcement detailing the issue of new shares to existing shareholders is a pre-determined ratio, which is approved in the board meeting. The company announces the split ratio on the record date and all the shareholders as on this date are eligible to receive additional shares. The existing share is split and hence the number of shares held increases but the face value of each share decreases.

(Pandey, 2015) The reason for the stock split of normal shares by a company is as follows: (1) To make trading in shares attractive. (2) To signal the possibility of profits in the future. (3) To give higher dividends to shareholders

A rights issue (offering) is made by the company to existing shareholders; this offer entitles the shareholders to buy additional shares of the company within a certain timeframe. These shares can be bought at a certain ratio usually dependent upon the number of shares held by each shareholder and the shares are offered at a discounted price. Rights are often transferable in the open market.

Rights are offered by the company when they need to raise additional capital. This usually occurs during times of economic slowdown when capital cannot be raised from other financial institutions. From the corporate perspective, this is an easy source of financing without raising the burden of debt for firms and for shareholders also it's a benefit to buy shares at a discounted price. Hence it becomes a win-win situation for both shareholders and corporate. 
There are also some negative perspectives which flow in the market along with rights issue. As rights issue are observed to be indicative of the weak financial position of the company unless it comes along with some other corporate action or explanation

\section{LITERATURE REVIEW}

(Fama, 1965) Proposed the efficient market hypothesis and suggested the presence of three forms of market efficiency: (1) Strong Form, (2) Semi-Strong Form

and (3) Weak Form of Market Efficiency. The strong form of market efficiency is where the prices reflect both publicly available and insider information; it is the strongest form of market. It also implies that the market information cannot be used for prediction of future prices, the technical analysis, fundamental analysis as well as the insider information are of no use in predicting future prices.

The semi-strong form of market efficiency is where stock prices reflect public information which implies that changes in stock prices are on account of public information. The weak form of market efficiency is where changes are stock prices are random and investors cannot make more than average returns with any kind of investment strategy. (Osei, 1998) Market efficiency is not only on account of information which is free and available on time but also on account of those who trade and analyze market information. The analytical and interpretational skill of these traders influences the information which flows in the market and their willingness to obtain such information.

(Muhammad \&Baig, 2010) Event Study Methodology has been most popularly used to investigate the presence of the semi-strong form of market efficiency. Information disclosures related to dividends and earnings announcements, macroeconomic variables, stock repurchase announcements, and mergers and acquisitions, etc., have been investigated in different studies to test the semi-strong form market efficiency.

Stock prices and dividends relation has been researched upon abundantly and there is sufficient literature which supports and opposes this relation. (Graham \& Dodd, 1951)Indicate the existence of relevance between stock prices and dividends. (Lintner, 1964) Firms increase dividends under the belief that this increase in surplus is permanent. (Bhattacharya, 1979) There is the existence of asymmetric information between the shareholders and management of the firms, therefore any change in dividends conveys information which is sensitive. (Black, 1976)\&(Easterbrook, 1984) have indicated that increase in dividends by management has a positive impact on shareholders, as dividends are paid out of excess funds and this balance is derived only after the funding of all other expenses. Therefore the increase in dividends would result in positive changes in stock prices and vice versa. (Muhammad \& Baig, 2010) Public announcement of dividend should not result in abnormal returns for investors this accounts for the existence of a semi-strong form of market efficiency, which postulates that stock prices incorporate all expected future dividends. Therefore there should not exist any abnormality in stock returns before and after the ex-dividend date.

(Elton \& Gruber, 1970) In one of the oldest study on the investors' interest in the dividend, have illustrated that the preference towards dividends and capital gains from investments in security is on account of taxation. According to their theory investors are interested in after-tax returns from stocks.

(Kalay, 1982)Argue that marginal tax rates are not the only factor that influences the ex-day phenomenon. He suggests that there are forces, caused by short term trades that reduce any tax-induced effects. In this type of short term trades or transaction cost model arbitrage traders attempt to eliminate any difference between the price change and the dividend amount that is caused by tax clienteles. According to this model transactions costs are the final restriction that keeps the price drop from adjusting the same amount of dividend. There are opposing beliefs on the importance of tax as a motivation for equity investment. (Guo, 2006) A study in Taiwan Stock Markets reveals that there exists a positive association between the number of stock bonuses and firms operating performance. (Fernando \& Guneratne, 2009) Study experimented on stock price performance on and around bonus issue announcements in Colombo Stock Exchange over period 1991 to 2007 using alternative return-generating models; market-adjusted model, mean-adjusted model and risk-adjusted model with the intention of providing a methodological triangulation the context of event study was performed.

(Peterson, 1971) After a bonus issue announcement, it is usually observed that there is an increase in stock price. This increase may be accounted for due to the informational content of the bonus issue announcement. (Nelson, 1965) Study on rights issue was conducted in the US during the period 1946-1957 with the data of 380 rights offerings. The results indicated that investor returns were not affected on account of rights issue around six months period before and after the announcement. (Loderer

\& Zimmermann, 1988)Investigation in Switzerland Market on 122 rights issue announcement during 1973-1983 also indicated that there were insignificant average abnormal returns. Thus, indicating no effect of the announcement. Madhuri, Thenmozhi, and Kumar (2003) In their study in Indian markets found a negative reaction to the bonus issue announcement.

Their conclusions indicated that there was under-reaction from the market. Mishra (2005), examined the stock price reaction to the information content of the bonus issue. 
The results indicated significant positive abnormal returns for a five-day period prior to the bonus announcement. The results indicated the semi-strong market efficiency of the Indian stock market. (Suresh \& Naidu, 2016) Found no evidence of wealth effect on Nifty stocks and the existence of significant average abnormal returns on the event day. The study was conducted on Nifty Stocks.

(Ball, Brown , \& Finn , 1977)Studied 193 listed firms from Melbourne/ Perth Stock Exchanges over a period of 12 years from 1958 to 1970 . Monthly data was used and event study methodology was applied for analysis. The results indicated positive abnormal returns. Thus concluding the Australian markets were efficient with respect to right issue announcement information.(White \& Lusztig, 1980) Used pooled cross-sectional time series model on data from daily security returns to examine 90 rights issues over the period of 10 years from 1962 to 1972 in the U.S. markets. Their analysis indicated negative reaction from markets for rights issue announcement of the stock prices to the rights issues announcements.

(Lovric, Lovric, \& Spronk, 2008)Suggested a financial model that can be used to build stylized representations of individual investors and further studied using the paradigm agent-based artificial financial markets. (Mittal \& Vyas, 2008) A study presented the relationship between demographic characteristics and the investment personality exhibited by investors. In this study, Indian investors have been classified as four dominant personalities namely casual, technical, informed and cautious.

(Harsha \& Kerav, 2012)Study attempted to understand the factors which influence the decision of investors in to purchase equity shares. It was found that firm image, personal financial position, advocate recommendations, track record, relevance to the community, neutral information, economic factors, and individual dynamics were the most influential factors.

(Pawar, 2013) Conducted a study on investor behavior towards market information in Indian markets. The conclusions of the study indicate that investor prefers to wait and watch before making their investment decision on most information, and analyze the information which could alter the risk profile of companies.

(Jain \& Mandot, 2012) Study on individual investors in Rajasthan was conducted to understand the relation between demographic factors and investment decision. It was found that demographic factors like age, marital status, gender, city, income level, market knowledge, occupations, and qualifications have a major impact. (Sharma \& Gupta, 2011) Concluded through his study that investment decision is mainly influenced by risk, return, peer influence, recommendations of financial advisors and market trends.

\section{OBJECTIVES \& HYPOTHESES}

$\mathrm{H}_{1}$ : There is an association between perceptions of investors on corporate actions across two cities.

$\mathrm{H}_{2}$ : There is an association between the perception of investors on corporate actions and age of investors across two cities.

$\mathrm{H}_{3}$ : There is an association between the perception of investors on corporate actions and education level of investors across two cities.

$\mathrm{H}_{4}$ : There is an association between the perception of investors on corporate actions and income level of investors across two cities.

$\mathrm{H}_{5 \text { : }}$ There is an association between the perception of investors on corporate actions and investing experience of investors across two cities.

\section{DESCRIPTION OF PILOT STUDY}

A pilot study was conducted by taking feedback from 50 individual investors located in Hyderabad city. The respondents were identified through snowball sampling method and references through acquaintances. For the purpose of content validity, the survey instrument was revised and altered based on the feedback from academicians and personnel working in the area of Capital Markets

The present study includes a survey of individual equity investors from Hyderabad and Mumbai. Final feedback from the sample has been collected from June 2016 to December 2018 simultaneously from both the places. One method of data collection was through questionnaires distribution to respective Demat sections of Financial Institutions after seeking permission from the branch manager. It was found that only $60-80 \%$ of questionnaire feedback could be received back. The reason for not receiving another questionnaire was either misplacement of document or poor investor response (i.e.). In some cases where

the bank representatives of the demat section were not ready to receive the questionnaire for data collection, it was personally administered. In this process, it was found that few respondents were not prepared to fill the questionnaire due to various reasons.

The other method adopted for data collection was through Investor Awareness Program. During these programs questionnaire was distributed to all the visiting investors as they entered the venue for investor awareness program and the same was collected back at the end of the program but it was not possible to collect the hardcopy from all, a few of them left before completion of the program, and few others who were coming late to the program could not find time to fill the questionnaire during the 
program. A sample of 861 feedbacks has been collected from a distributed questionnaire which was approximately 1250 in both places. The final sample consists of 662 responses which include 353 from Mumbai and 309 from Hyderabad from 662 responses.

\section{ANALYSIS AND INTERPRETATION}

\section{RELIABILITY TEST RESULTS}

It is a measure for consistency between multiple measurements of variables and is conducted to ensure that the responses are not widely varying. Cronbach's alpha is a measure to test the internal consistency of items in a scale. It is a measure of scale reliability or efficiency of reliability. Hair, et.al (2011) states in his book on "Multivariate analysis" Cronbach's alpha is a measure of reliability that ranges from 0 to 1 , with values of 0.60 t0 0.70 deemed to be the lower limit of acceptability using SPSS software.

Table 1 Results of Reliability test

\begin{tabular}{|l|l|l|}
\hline $\begin{array}{c}\text { Subscale } \\
\text { Variables }\end{array}$ & $\begin{array}{c}\text { Cronbach's } \\
\text { Alpha }\end{array}$ & $\begin{array}{c}\text { No. of } \\
\text { items }\end{array}$ \\
\hline $\begin{array}{c}\text { (H1 to H6) } \\
\text { Corporate } \\
\text { Actions }\end{array}$ & 0.756 & 4 \\
\hline
\end{tabular}

Source: From the analysis of primary data using SPSS 20 software.

The alpha coefficient for individual subscale and overall items, suggests that the items have relatively high internal consistency. (Note that a reliability coefficient of .60 or higher is considered "acceptable" in most social science research situations). In the present study, the reliability level of subscale variables and overall variables the alpha values have been found to be satisfactory

\section{The sample used for the study}

A pilot study was conducted by taking feedback from 50 individual investors located in Hyderabad city. The respondents were identified through snowball sampling method and references through acquaintances. For the purpose of content validity, the survey instrument was revised and altered based on the feedback from academicians and personnel working in the area of Capital Markets

The present study includes a survey of individual equity investors from Hyderabad and Mumbai. Final feedback from the sample has been collected from June 2014 to October 2015 simultaneously from both the places. One method of data collection was through questionnaires distribution to respective Demat sections of Financial Institutions after seeking permission from the branch manager. It was found that only $60-80 \%$ of questionnaire feedback could be received back. The reason for not receiving another questionnaire was either misplacement of document or poor investor response (i.e.). In some cases where the bank representatives of the demat section were not ready to receive the questionnaire for data collection, it was personally administered. In this process, it was found that few respondents were not prepared to fill the questionnaire due to various reasons.

The other method adopted for data collection was through Investor Awareness Program. During these programs questionnaire was distributed to all the visiting investors as they entered the venue for investor awareness program and the same was collected back at the end of the program but it was not possible to collect the hardcopy from all, a few of them left before completion of the program, and few others who were coming late to the program could not find time to fill the questionnaire during the program. A sample of 861 feedbacks has been collected from a distributed questionnaire which was approximately 1250 in both places. The final sample consists of 662 responses which include 353 from Mumbai and 309 from Hyderabad from 662 responses.

Table 2 List of Corporate Actions Included for the Study

\begin{tabular}{|l|l|}
\hline S.No. & Corporate Actions \\
\hline 1 & Dividend Announcement \\
\hline 2 & Bonus Announcement \\
\hline 3 & Rights Issue Announcement \\
\hline 4 & Stock Split Announcement \\
\hline
\end{tabular}


The perception of investors has been mapped using a survey method for the four corporate actions mentioned above. These have been selected based on their popularity, availability of information and importance. Feedback from investors is taken based on five points Likert scale where " 1 " represented "strongly disagree" and "5" meant "strongly agree.

Graphical Representation of the Investor feedback on the importance of each Corporate Action

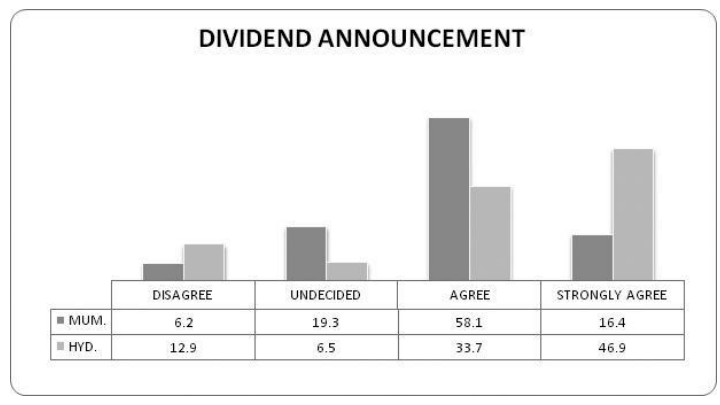

Source: From primary data analysis using SPSS 20 software.

Figure 5, Investor Perception on Importance of Dividend Issue Announcement

Investor perception in the importance of the dividend announcement was found to be positive from both the cities. As observed $75 \%$ of investors from Mumbai and $80 \%$ investors from Hyderabad on either agreed or strongly agreed to the statement that "dividend announcements are important information for equity investing decision".

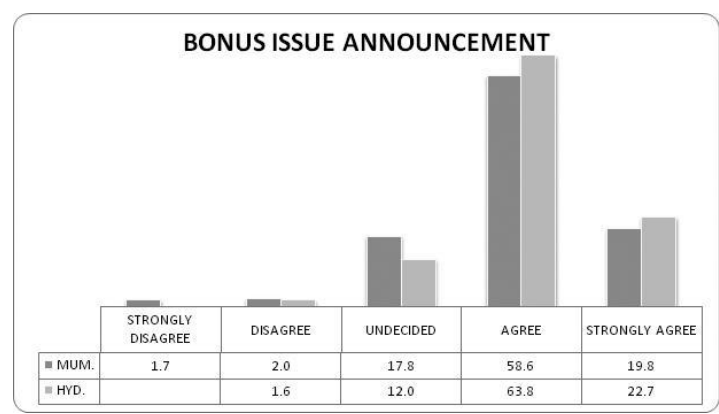

Source: From primary data analysis using SPSS 20 software.

Figure 2, Investor Perception on Importance of Bonus Issue Announcement

Majority of individual investors, that is, $78.4 \%$ of individual investors from Mumbai and $86.5 \%$ from Hyderabad either agree or strongly agree to the statement that information on bonus announcements has a positive impact on equity returns. At the same time, it can also be observed that a section of investors is still not sure about the importance of

$\mathrm{H} 2(\mathrm{~b})$ : There is an association between perceptions of investors on bonus issue announcement across two cities. $\mathrm{H} 2$ (c): There is an association between perceptions of investors on stock split announcement across two cities.

$\mathrm{H} 2$ (d): is an association between perceptions of investors on rights issue announcement across two cities.

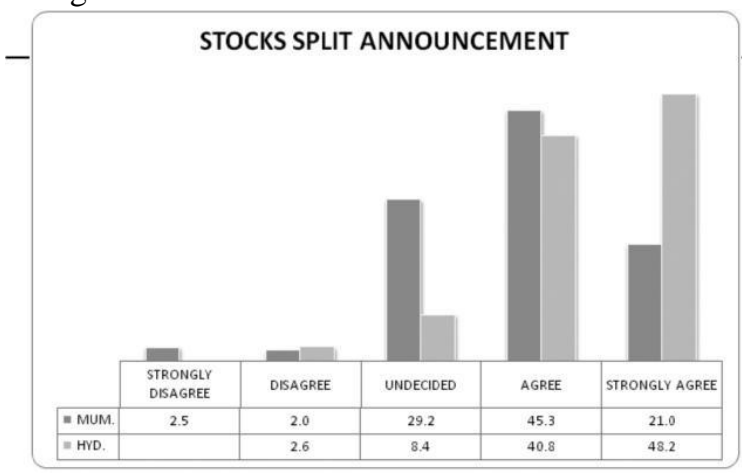

Table 7

d Source: From primary data analysis using SPSS 20 software.

Figure 3, Investor Perception on the Importance of Each Stock Split Announcement

For stock split announcement we find that a section of investors from Mumbai indicate they are not sure about the impact of this announcement, but it can be observed that approximately $89 \%$ of investors agree or strongly agree that this announcement is very important.

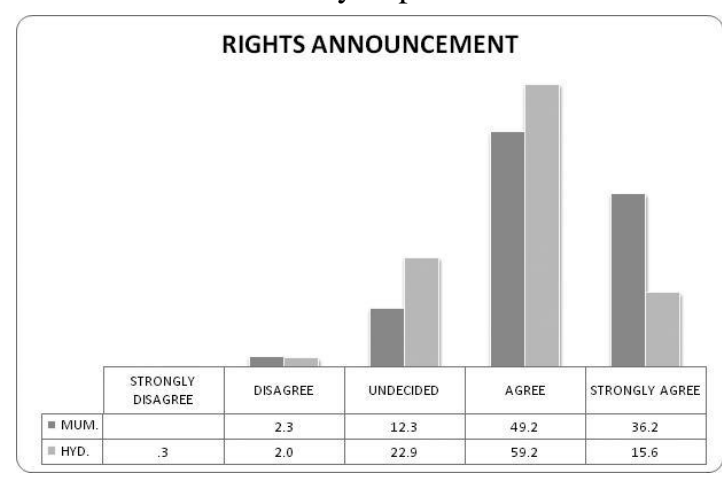

Source: From primary data analysis using SPSS 20 software.

Figure 4, Investor Perception on Importance of Rights Issue Announcement

It can be found that except for a margin of investors in the sample all other agreements that rights announcement of companies affects their equity returns. A small section of investors from both cities 2.3\% from Mumbai and 2.3\% from Hyderabad disagree towards the importance of rights issue announcements. 


\section{RESULTS FROM ANALYSIS}

Association between City of Residence and Investor Perception on Corporate Actions

$\mathrm{H}_{2}$ : There is an association between perceptions of investors on corporate actions across two cities.

$\mathrm{H}_{2(\mathrm{a})}$ : There is an association between perceptions of investors on dividend announcement across two cities.

Summary from Analysis of Chi-Square test between Variables: City of Residence and Corporate Actions

\begin{tabular}{|c|c|c|c|c|}
\hline $\begin{array}{l}\text { Hypothes } \\
\text { es }\end{array}$ & $\begin{array}{l}\text { Variables City } \\
\text { Percepti } \\
\text { and on } \\
\text { corporat } \\
\text { on e } \\
\text { Announcem } \\
\text { ents) }\end{array}$ & \begin{tabular}{|l} 
C h \\
i - \\
are \\
areu \\
valu
\end{tabular} & d. & $\begin{array}{l}\text { A s y } \\
\text { m p. } \\
\text { S i g . } \\
\text { (2-side } \\
\text { d) }\end{array}$ \\
\hline H12(a) & $\mid \begin{array}{ll}\mathrm{D} \text { i } \mathrm{v} \text { i d } & \\
& \\
\text { Announce } & \\
\text { ment } & y \\
\text { companies } & \end{array}$ & $20^{99.2}$ & 4 & .000 \\
\hline H12(b) & $\begin{array}{l}\mathrm{B} \\
\mathrm{o} \quad \mathrm{n} \mathrm{u} \\
\text { Announce } \\
\text { ment } \\
\text { companies }\end{array}$ & $63^{10.4}$ & 4 & .033 \\
\hline H12(c) & \begin{tabular}{|lr} 
Rig & Is \\
hts & sue \\
Announce & \\
ment & y \\
companies & \\
\end{tabular} & $55^{42.2}$ & 4 & .000 \\
\hline $\mathrm{H} 12(\mathrm{~d})$ & \begin{tabular}{|rr} 
Sto & S \\
ck & plit \\
Announce & \\
ment & $y$ \\
companies &
\end{tabular} & 31 & 4 & .000 \\
\hline
\end{tabular}

Source: From primary data analysis using SPSS 20 software

A chi-square test of association was calculated for comparing perceptions of investors on corporate action between two cities (Hyderabad \& Mumbai). A significant interaction was found for all corporate announcements, indicating that city of residence was vital and affected the perceptions of individual investors. From the graphical representation of data, it can also be verified that there was a very small section of investors who disagreed that corporate actions had an effect on equity returns. It is also found that a section of investors was undecided on the important of these factors.

Association between Age of Investor and Investor Perception on Corporate Actions across two cities $\mathrm{H}_{3}$ :
There is an association between the perception of investors on corporate actions and age of investors across two cities.

$\mathrm{H}_{3(\mathrm{a})}$ : There is an association between perceptions of investors on dividend announcement and age across two cities.

$\mathrm{H}_{3(\mathrm{~b})}$ : There is an association between perceptions of investors on bonus issue announcement and age across two cities.

$\mathrm{H}_{3(\mathrm{c})}$ : There is an association between perceptions of investors on stock split announcement and age across two cities.

$\mathrm{H}_{3(\mathrm{~d})}$ : There is an association between perceptions of investors on rights issue announcement and age across two cities.

\section{Table 8}

Frequency Analysis of Age of Investor

\begin{tabular}{|c|c|c|c|c|c|c|}
\hline $\begin{array}{l}\text { City } \\
\text { Age of } \\
\text { Investor }\end{array}$ & $\begin{array}{l}\text { HYDERAE } \\
\text { Frequency }\end{array}$ & $\begin{array}{l}\text { BAD } \\
\text { Percent }\end{array}$ & $\begin{array}{l}\text { MUMBAI } \\
\text { Frequency }\end{array}$ & Percent & $\begin{array}{l}\text { TOTAL } \\
\text { Frequency }\end{array}$ & Percent \\
\hline $\begin{array}{l}\text { Below } 25 \\
\text { years }\end{array}$ & 24 & 7.8 & 15 & 4.2 & 39 & 5.9 \\
\hline $\begin{array}{l}\text { B etween } \\
(26-35) \\
\text { years }\end{array}$ & 78 & 25.2 & 114 & 32.3 & 192 & 29.0 \\
\hline $\begin{array}{l}\text { Between } \\
(36-45) \\
\text { years }\end{array}$ & 83 & 26.9 & 85 & 24.1 & 168 & 25.4 \\
\hline $\begin{array}{l}\text { Between } \\
(46-55) \\
\text { years }\end{array}$ & 60 & 19.4 & 78 & 22.1 & 128 & 20.8 \\
\hline $\begin{array}{l}\text { Above } 55 \\
\text { years }\end{array}$ & 64 & 20.7 & 61 & 17.3 & 125 & 18.9 \\
\hline Total & 309 & 100 & 353 & 100 & 662 & 100 \\
\hline
\end{tabular}

Above table 5 presents frequency analysis of investors across two cities and five categories. It is noticed that most investors from Hyderabad belong to the age group of 36 to 45 years, and those from Mumbai mostly belong to the age group of 26 to 35 years age group. Overall we find that $29 \%$ of investors are in the age bracket of 26 to 35 years, there are very few young investors who are below the age of 25 years. One noticeable aspect is that approximately $19 \%$ of investors are above the age of 55 years, by this means we understand that a considerable proportion of sample belongs to individuals who are old and yet interested in equity investing. 
Table 9

Summary from Analysis of Chi-Square test between Variables: Age of Investor and Corporate Actions

\begin{tabular}{|c|c|c|c|c|c|c|c|}
\hline \multirow[t]{3}{*}{ Hyp. } & \multirow{2}{*}{$\begin{array}{l}\text { CITY } \\
\text { Corporate }\end{array}$} & \multicolumn{3}{|c|}{ HYDERABAD } & \multicolumn{3}{|c|}{ MUMBAI } \\
\hline & & Chi- & d.f. & Appx. & Chi- & d.f. & Appx. \\
\hline & Action & $\begin{array}{l}\text { square } \\
\text { value }\end{array}$ & & sig. & $\begin{array}{l}\text { square } \\
\text { value }\end{array}$ & & sig. \\
\hline H3(a) & $\begin{array}{l}\text { Dividend } \\
\text { Announcement }\end{array}$ & 21.026 & 9 & 0.012 & 55.619 & 9 & 0.000 \\
\hline $\mathrm{H} 3$ (b) & $\begin{array}{l}\text { Bonus Issue } \\
\text { Announcement }\end{array}$ & 60.215 & 9 & 0.000 & 100.41 & 12 & 0.000 \\
\hline $\mathrm{H} 3(\mathrm{c})$ & $\begin{array}{l}\text { Stock Split } \\
\text { Announcement }\end{array}$ & 33.116 & 9 & 0.000 & 123.24 & 12 & 0.000 \\
\hline $\mathrm{H} 3(\mathrm{~d})$ & $\begin{array}{l}\text { Rights Issue } \\
\text { Announcement }\end{array}$ & 34.688 & 9 & 0.000 & 64.123 & 12 & 0.000 \\
\hline
\end{tabular}

The above table 9 presents the results of the chi-square test conducted to test for association between four corporate actions and city of residence of investors. It is believed that the city of residence has an impact on the perceptions of investors regarding the importance of corporate actions for making equity investment decisions. The results indicate that the significance values are less than 0.05 thus indicating that city of residence has an impact on investor perceptions.

Association between Education Level of Investor and Perception of Corporate Actions across two cities

$\mathrm{H}_{4}$ : There is an association between the perception of investors on corporate actions and education level of investors across two cities.

$\mathrm{H}_{4(\mathrm{a})}$ : There is an association between perceptions of investors on dividend announcement and education level across two cities.

$\mathrm{H}_{4(\mathrm{~b})}$ : There is an association between perceptions of investors on bonus issue announcement and education level across two cities.

$\mathrm{H}_{4(\mathrm{c})}$ : There is an association between perceptions of investors on stock split announcement and education level across two cities.

$\mathrm{H}_{4(\mathrm{~d})}$ : There is an association between perceptions of investors on rights issue announcement and education level across two cities.
Table 10

Frequency Analysis of Education Level of Investors

\begin{tabular}{|c|c|c|c|c|c|c|c|}
\hline & City & $\begin{array}{l}\text { HYDF } \\
\text { AD }\end{array}$ & RAB & $\begin{array}{l}\text { MUM } \\
\text { BAI }\end{array}$ & & $\begin{array}{l}\text { TOTA } \\
\mathrm{L}\end{array}$ & \\
\hline & $\begin{array}{l}\text { Educatio } \\
n\end{array}$ & & & & & & \\
\hline & $\begin{array}{l}\text { Level } \\
\text { of } \\
\text { Invest } \\
\text { or }\end{array}$ & $\begin{array}{l}\text { Frequ } \\
\text { ency }\end{array}$ & $\begin{array}{l}\text { Perc } \\
\text { ent }\end{array}$ & $\begin{array}{l}\text { Freq } \\
\text { uency }\end{array}$ & $\begin{array}{l}\text { Perc } \\
\text { ent }\end{array}$ & $\begin{array}{l}\text { Frequ } \\
\text { ency }\end{array}$ & $\begin{array}{l}\text { Perc } \\
\text { ent }\end{array}$ \\
\hline 1 & $\begin{array}{l}\text { No formal } \\
\text { educatio } \\
n \\
\text { Primar } \\
\mathrm{y} \text { (up }\end{array}$ & 9 & 2.9 & 2 & .6 & 11 & 1.7 \\
\hline 2 & $\begin{array}{l}\text { to class } \\
\text { 5) } \\
\text { Class }\end{array}$ & 12 & 3.9 & 1 & .3 & 12 & 2.0 \\
\hline 3 & $\begin{array}{l}10 \\
\text { Intermediat } \\
\mathrm{e}\end{array}$ & 18 & 5.8 & 2 & .6 & 20 & 3.0 \\
\hline 4 & \begin{tabular}{|l} 
(plus \\
2) \\
Graduati
\end{tabular} & 48 & 15.5 & 36 & 10.2 & 84 & 12.7 \\
\hline 5 & on & 125 & 40.5 & 181 & 51.3 & 306 & 46.2 \\
\hline 6 & $\begin{array}{l}\text { P o s t } \\
\text { Graduati } \\
\text { on }\end{array}$ & 74 & 23.9 & 105 & 29.7 & 179 & 27.0 \\
\hline & Technical/ & & & & & & \\
\hline 7 & $\begin{array}{l}\text { Profession } \\
\text { al }\end{array}$ & 20 & 6.5 & 25 & 7.1 & 45 & 6.8 \\
\hline 8 & $\begin{array}{l}\text { Others } \\
\text { Tot } \\
\text { al }\end{array}$ & $\begin{array}{l}3 \\
309\end{array}$ & $\begin{array}{l}1.0 \\
100\end{array}$ & $\begin{array}{l}1 \\
353\end{array}$ & $\begin{array}{l}.3 \\
100\end{array}$ & $\begin{array}{l}4 \\
662\end{array}$ & $\begin{array}{l}0.6 \\
100\end{array}$ \\
\hline
\end{tabular}

From the table 10 which presents the frequency analysis of education level of investors from two cities

and across eight levels, it can be found that overall most of the investors are from level 5 (i.e.) have graduation level of education. For Hyderabad and Mumbai, also a similar trend is observed. There are very few investors who belong to either category 1 or 8 (i.e.) with no formal education and also those who do not belong to any of the mentioned categories. From the data, it can be noticed that most of the investors are well qualified, at least have education level from intermediate to post-graduation. From Hyderabad about $79.9 \%$ of investors and for Mumbai, $91.2 \%$ of investors belong to either of three levels mentioned earlier. 
Table 11

Summary from Analysis of Chi-Square test between Variables: Education Level of Investor and Corporate Actions

\begin{tabular}{|c|c|c|c|c|c|c|c|}
\hline \multirow[t]{2}{*}{ Hyp. } & \multirow{2}{*}{$\begin{array}{l}\text { CITY } \\
\text { CORPORATE }\end{array}$} & \multicolumn{3}{|c|}{ HYDERABAD } & \multicolumn{3}{|c|}{ MUMBAI } \\
\hline & & Chi- & d.f. & Appx. & Chi- & d.f. & Appx. \\
\hline & ACTION & $\begin{array}{l}\text { square } \\
\text { value }\end{array}$ & & sig. & $\begin{array}{l}\text { square } \\
\text { value }\end{array}$ & & sig. \\
\hline $\mathrm{H} 4$ (a) & Dividend & 21.026 & 9 & 0.012 & 55.619 & 9 & 0.000 \\
\hline $\mathrm{H} 4$ (b) & Bonus Issue & 60.215 & 9 & 0.000 & 100.41 & 12 & 0.000 \\
\hline $\mathrm{H} 4(\mathrm{c})$ & Stock Split & 33.116 & 9 & 0.000 & 123.24 & 12 & 0.000 \\
\hline $\mathrm{H} 4$ (d) & Rig hts Issue & 34.688 & 9 & 0.000 & 64.123 & 12 & 0.000 \\
\hline & Announcement & & & & & & \\
\hline
\end{tabular}

The above table presents the results of the chi-square test conducted to test for association between four corporate actions and education level of residence of investors. It is believed that the education level of investors has an impact on the perceptions of investors regarding the importance of corporate actions for making equity investment decisions. The results indicate that the significance values are less than 0.05 thus indicating that education level has an impact on investor perceptions.

Association between Income Level of Investor and Perception of Corporate Actions across two cities Hypotheses

$\mathrm{H}_{5}$ : There is an association between the perception of investors on corporate actions and education level of investors across two cities.

$\mathrm{H}_{5(\mathrm{a})}$ : There is an association between perceptions of investors on dividend announcement and income level across two cities.

$\mathrm{H}_{5(\mathrm{~b})}$ : There is an association between perceptions of investors on bonus issue announcement and income level across two cities.

$\mathrm{H}_{5(\mathrm{c})}$ : There is an association between perceptions of investors on the stock split announcement and income

level across two cities.

$\mathrm{H}_{5(\mathrm{~d})}$ : There is an association between perceptions of investors on rights issue announcement and income level across two cities.
Table 12

Frequency Analysis of Income Level of Investors

\begin{tabular}{|c|c|c|c|c|c|c|c|}
\hline \multirow[t]{2}{*}{ Level } & \multirow{2}{*}{\begin{tabular}{|l} 
City \\
Income \\
Level of \\
Investor
\end{tabular}} & \multicolumn{2}{|c|}{ HYDERABAD } & \multicolumn{2}{|c|}{ MUMBAI } & \multicolumn{2}{|l|}{ TOTAL } \\
\hline & & $\begin{array}{c}\begin{array}{c}\text { Frequ } \\
\text { ency }\end{array} \\
\end{array}$ & $\begin{array}{c}\text { Perc } \\
\text { ent }\end{array}$ & $\begin{array}{c}\text { Frequ } \\
\text { ency }\end{array}$ & $\begin{array}{c}\text { Perc } \\
\text { ent }\end{array}$ & $\begin{array}{c}\text { Frequ } \\
\text { ency }\end{array}$ & $\begin{array}{c}\text { Perc } \\
\text { ent }\end{array}$ \\
\hline 1 & $\begin{array}{ll}\text { Below } & \text { Rs. } \\
15,000 & \text { per } \\
\text { month } & \\
\end{array}$ & 38 & 12.3 & 39 & 11 & 77 & 11.6 \\
\hline 2 & $\begin{array}{l}\text { B e t w e e } \mathrm{n} \\
\mathrm{R} \quad \mathrm{s} \\
15,001 \\
\mathrm{Rs} .30,000 \\
\text { per month }\end{array}$ & 87 & 28.2 & 118 & 33 & 205 & 31.0 \\
\hline 3 & \begin{tabular}{|l} 
Between Rs. \\
30,001 to \\
Rs . 50,000 \\
per month
\end{tabular} & 95 & 30.7 & 144 & 41 & 239 & 36.1 \\
\hline 4 & $\begin{array}{l}\text { Between Rs. } \\
50,001 \quad \text { to } \\
\text { Rs. } 1,00,000 \\
\text { per month }\end{array}$ & 76 & 24.6 & 45 & 12 & 121 & 18.3 \\
\hline 5 & \begin{tabular}{|l} 
Between Rs. \\
$1,00,001 \quad$ to \\
Rs. $2,00,000$ \\
per month
\end{tabular} & 12 & 4.2 & 7 & 2 & 20 & 3.0 \\
\hline 6 & Total & 309 & 100 & 353 & 100 & 662 & 100 \\
\hline
\end{tabular}

Table.12 presents a frequency analysis of the income level of investors in two cities across five levels of segmentation. It is found that for Hyderabad majority of investors are from level 2 and 3, for Mumbai also a similar trend is observed. It can also be noticed that investors from income level 5 are very few in percentage from both the cities.

Table 13

Summary from Analysis of Chi-Square test between Variables: Income Level of Investor and Corporate Actions

\begin{tabular}{|c|c|c|c|c|c|c|c|}
\hline Hyp. & $\begin{array}{l}\text { CITY } \\
\text { C O R P O } \\
\text { R A T E } \\
\text { ACTION }\end{array}$ & $\begin{array}{l}\text { HYDEI } \\
\mathrm{C} \mathrm{h} \mathrm{i} \mathrm{-} \\
\text { square } \\
\text { value }\end{array}$ & $\mathrm{ABA}$ & $\begin{array}{l}\text { Appx. } \\
\text { sig. }\end{array}$ & $\begin{array}{l}\text { MUMB } \\
\mathrm{C} \mathrm{h} \mathrm{i} \mathrm{-} \\
\text { square } \\
\text { value }\end{array}$ & d.f. & $\begin{array}{l}\text { Appx } \\
\text { sig. }\end{array}$ \\
\hline $\mathrm{H} 5$ (a) & $\begin{array}{l}\text { Dividend } \\
\text { Announcement }\end{array}$ & 120.89 & 12 & 0.000 & 19.910 & 12 & 0.069 \\
\hline H5(b) & $\begin{array}{l}\text { Bonus Issue } \\
\text { Announcement }\end{array}$ & 48.691 & 12 & 0.000 & 45.100 & 16 & 0.000 \\
\hline $\mathrm{H} 5$ (c) & $\begin{array}{l}\text { Stock Split } \\
\text { Announcement }\end{array}$ & 66.363 & 12 & 0.000 & 32.093 & 16 & 0.010 \\
\hline $\mathrm{H} 5$ (d) & $\begin{array}{l}\text { Rights Issue } \\
\text { Announcement }\end{array}$ & 39.157 & 12 & 0.000 & 26.103 & 16 & 0.053 \\
\hline
\end{tabular}

The above table presents the results of the chi-square

and across eight levels, it can be found that overall most of the investors are from level 5 (i.e.) have graduation level of education. For Hyderabad and Mumbai, also a similar trend is observed. There are very few investors who belong to either category 1 or 8 (i.e.) with no formal education and also those who do not belong to any of the mentioned categories. From the data, 
it can be noticed that most of the investors are well qualified, at least have education level from intermediate to post-graduation. From Hyderabad about $79.9 \%$ of investors and for Mumbai, $91.2 \%$ of investors belong to either of three levels mentioned earlier.

\section{Table 11}

Summary from Analysis of Chi-Square test between Variables: Education Level of Investor and Corporate Actions

\begin{tabular}{|l|l|l|l|l|l|l|l|}
\hline Hyp. & CITY & \multicolumn{3}{|l|}{ HYDERABAD } & \multicolumn{2}{l|}{ MUMBAI } \\
\hline & $\begin{array}{l}\text { CORPORATE } \\
\text { ACTION }\end{array}$ & $\begin{array}{l}\text { Chi- } \\
\text { square } \\
\text { value }\end{array}$ & d.f. & $\begin{array}{l}\text { Appx. } \\
\text { sig. }\end{array}$ & $\begin{array}{l}\text { Chi- } \\
\text { square } \\
\text { value }\end{array}$ & $\begin{array}{l}\text { d.f. } \\
\text { Appx. } \\
\text { sig. }\end{array}$ \\
\hline H4(a) & $\begin{array}{l}\text { Dividend } \\
\text { Announcement }\end{array}$ & 21.026 & 9 & 0.012 & 55.619 & 9 & 0.000 \\
\hline H4(b) & $\begin{array}{l}\text { Bonus Issue } \\
\text { Announcement }\end{array}$ & 60.215 & 9 & 0.000 & 100.41 & 12 & 0.000 \\
\hline H4(c) & $\begin{array}{l}\text { Stock Split } \\
\text { Announcement }\end{array}$ & 33.116 & 9 & 0.000 & 123.24 & 12 & 0.000 \\
\hline H4(d) & $\begin{array}{l}\text { Rig hts Issue } \\
\text { Announcement }\end{array}$ & 34.688 & 9 & 0.000 & 64.123 & 12 & 0.000 \\
\hline
\end{tabular}

The above table presents the results of the chi-square test conducted to test for association between four corporate actions and education level of residence of investors. It is believed that the education level of investors has an impact on the perceptions of investors regarding the importance of corporate actions for making equity investment decisions. The results indicate that the significance values are less than 0.05 thus indicating that education level has an impact on investor perceptions.

Association between Income Level of Investor and Perception of Corporate Actions across two cities Hypotheses

$\mathrm{H}_{5}$ : There is an association between the perception of investors on corporate actions and education level of investors across two cities.

$\mathrm{H}_{5(\mathrm{a})}$ : There is an association between perceptions of investors on dividend announcement and income level across two cities.

$\mathrm{H}_{5(\mathrm{~b})}$ : There is an association between perceptions of investors on bonus issue announcement and income level across two cities.

$\mathrm{H}_{5(\mathrm{c})}$ : There is an association between perceptions of investors on the stock split announcement and income level across two cities.

$\mathrm{H}_{5(\mathrm{~d})}$ : There is an association between perceptions of investors on rights issue announcement and income level across two cities.

Table 12

Frequency Analysis of Income Level of Investors

\begin{tabular}{|l|l|l|l|l|l|l|l|}
\hline \multirow{2}{*}{ Level } & City & \multicolumn{2}{|l|}{ HYDERABAD } & \multicolumn{2}{l|}{ MUMBAI } & TOTAL \\
\cline { 2 - 7 } & $\begin{array}{c}\text { Income } \\
\text { Level of } \\
\text { Investor }\end{array}$ & $\begin{array}{c}\text { Frequ } \\
\text { ency }\end{array}$ & $\begin{array}{c}\text { Perc } \\
\text { ent }\end{array}$ & $\begin{array}{c}\text { Frequ } \\
\text { ency }\end{array}$ & $\begin{array}{c}\text { Perc } \\
\text { ent }\end{array}$ & $\begin{array}{c}\text { Frequ } \\
\text { ency }\end{array}$ & $\begin{array}{c}\text { Perc } \\
\text { ent }\end{array}$ \\
\hline 1 & $\begin{array}{lllll}\text { Below } & \text { Rs. } \\
15,000 & \text { per }\end{array}$ & 12.3 & 39 & 11 & 77 & 11.6
\end{tabular}

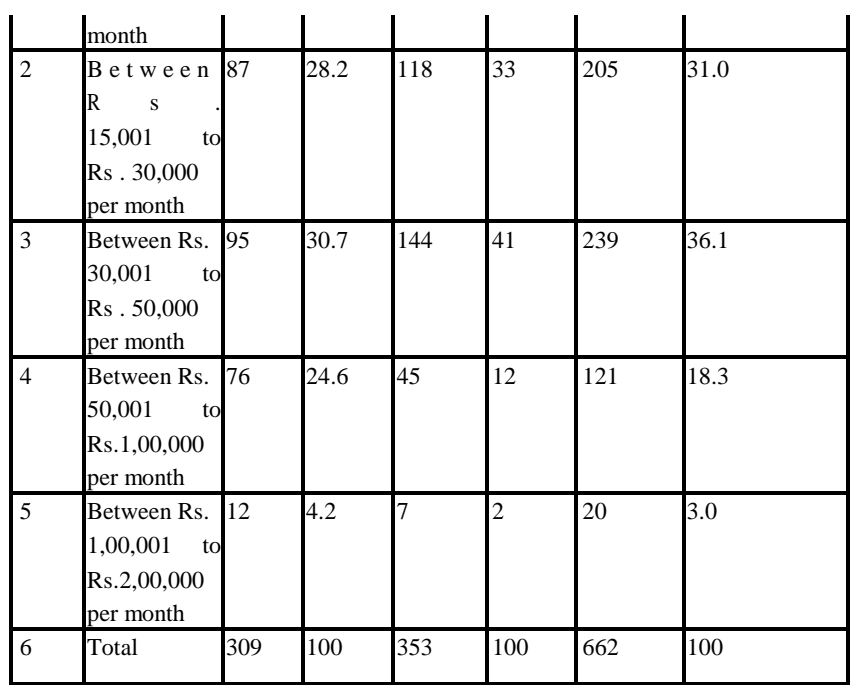

Table.12 presents a frequency analysis of the income level of investors in two cities across five levels of segmentation. It is found that for Hyderabad majority of investors are from level 2 and 3, for Mumbai also a similar trend is observed. It can also be noticed that investors from income level 5 are very few in percentage from both the cities.

Table 13

Summary from Analysis of Chi-Square test between Variables: Income Level of Investor and Corporate Actions

\begin{tabular}{|c|c|c|c|c|c|c|c|}
\hline \multirow[t]{2}{*}{ Нyp. } & & \multicolumn{3}{|c|}{ HYDERABAD } & \multicolumn{3}{|c|}{ MUMBAI } \\
\hline & $\begin{array}{l}\text { C O R P O } \\
\text { R A T E } \\
\text { ACTION }\end{array}$ & $\begin{array}{l}\mathrm{C} \mathrm{h} \mathrm{i} \mathrm{-} \\
\text { square } \\
\text { value }\end{array}$ & d.f. & $\begin{array}{l}\text { Appx. } \\
\text { sig. }\end{array}$ & $\begin{array}{l}\mathrm{C} \mathrm{h} \mathrm{i} \mathrm{-} \\
\text { square } \\
\text { value }\end{array}$ & d.f. & $\begin{array}{l}\text { Appx. } \\
\text { sig. }\end{array}$ \\
\hline H5(a) & $\begin{array}{l}\text { Dividend } \\
\text { Announcement }\end{array}$ & 120.89 & 12 & 0.000 & 19.910 & 12 & 0.069 \\
\hline H5(b) & $\begin{array}{l}\text { Bonus Issue } \\
\text { Announcement }\end{array}$ & 48.691 & 12 & 0.000 & 45.100 & 16 & 0.000 \\
\hline $\mathrm{H} 5(\mathrm{c})$ & $\begin{array}{l}\text { Stock Split } \\
\text { Announcement }\end{array}$ & 66.363 & 12 & 0.000 & 32.093 & 16 & 0.010 \\
\hline $\mathrm{H} 5(\mathrm{~d})$ & $\begin{array}{l}\text { Rights Issue } \\
\text { Announcement }\end{array}$ & 39.157 & 12 & 0.000 & 26.103 & 16 & 0.053 \\
\hline
\end{tabular}

The above table presents the results of the chi-square on stock prices of the nifty company, in the case of 61 days, 31 days and 11 days event window. Whereas ex-dividend day does not have such effect and in the case of ex-rights day significant effect if found only for 31 days event period.

Section-B of the chapter is related to the study on the perceptions of investors about the importance of these four events and its association with demographic variables (i.e.,) city of residence, age, education, income, and investing experience.

It contains five hypotheses $\mathrm{H}_{12}$ to $\mathrm{H}_{16}$. The analysis was performed using the chi-square test of association between variables, and the results indicate that in the case of the city and the corporate announcement there is an association. 
For variables such as age, income, and education the perception regarding the importance of corporate actions selected has a statistically significant association for stock splits event information seems to be perceived to be equally important across Hyderabad and Mumbai mostly. In the case of investing experience and perception, there is no such association found.

Overall it can be said that investors are conscious of the importance of corporate actions and its impact on their returns from both the cities.

\section{BIBLIOGRAPHY:}

1. Ball, R., Brown, P., \& Finn, F. J. (1977). Share capitalization changes, information, and the Australian equity market. Australian Journal of Finance, 105-117. Bhattacharya, S. (1979). Imperfect Information, Dividend Policy, and 'The Bird in Hand Fallacy". The Bell Journal of Economics, 259-270.

2. Black, F. (1976). The Dividend Puzzle. Journal of Portfolio Management, 5-8.

3. Easterbrook. (1984). Two Agency-Cost Explanations of Dividends. The American Economic Review, 650-659. Elton, E., \& Gruber, M. (1970). Marginal stockholder tax rates and the clientele effect. Review of Economics and Statistics, 68-74.

4. Fama, E. (1965). The Behavior of Stock Market Prices.

5. Journal of Business, 34-105.

6. Graham, \& Dodd. (1951). Security Analysis. New York: McGraw-Hill Book Company.

7. Groves, F. (2008). Corporate Actions A Concise Guide.

8. Hampshire, Britain: Harriman House Ltd.

9. Harsha, J., \& Kerav, P. (2012). Investors Behavior of Equity Investment: an empirical study of individual investors. GFJMR, 1-33.

10. Jain, D., \& Mandot, N. (2012). Impact of Demographic Factors on Investment Decision of Investors in Rajasthan. Journal of Arts, Science and Commerce, 81-92.

11. Kalay, A. (1982). The ex-dividend day behavior of stock prices: A re-examination of the clientele effect.

12. Journal of Finance, 1059-1070.

13. Lintner, J. (1964). Optimal Dividends and Corporate Growth Under Uncertainity. The Quarterly Journal of Economics, 49-95.

14. Loderer, C., \& Zimmermann, H. (1988). Stock Offerings in a different institutional setting: The swiss case. Journal of Banking and Finance, 353-378.

15. Lovric, Lovric, K. M., \& Spronk, J. (2008). A Conceptual Model of Investor Behaviour. r. Malhotra, M., Thenmozhi, M., \& Kumar, A. (2013). Evidence on changes in time varying volatility around bonus and rights issue announcements. International Journal of Emerging Markets.

16. Mittal, M., \& Vyas, R. K. (2008). Persnality Type and Investment Choice: An Empirical Study. The ICFAI University Journal of Behavioral Finance, 6-22.

17. Muhammad, A., \& Baig, H. H. (2010). The reaction of Stock Prices to Dividend Announcements and Market Efficiency in Pakistan. The Lahore Journal of Economics, 103-125.

18. Nelson. (1965). Price Effects in Rights Offerings.

19. Journal of Finance, 650-657.

20. Osei, K. (1998). Analysis of Factors Affecting the Development of an Emerging Capital Market: The Case of the Ghana Stock Market. African Economic Research Consortium Research, 76.

21. Pandey, I. M. (2015). Financial Management. New Delhi: Vikas Publications.
22. Pawar, I. (2013). Investment Pattern and Behaviour of Investors in Indian Capital Markets. Sumedh: Journal of Management, 1-21.

23. Peterson, R. (1971). Bonus Issues, Share Issues, Share Splits and Rights Issues. The Chartered Secretary, 198-207.

24. Shanmugasundaram, V., \& Balakrishnan, V. (2009). Behavioral Biases of Investors in Capital Markets. South Asian Journal of Socio-Political Studies, 99-102. Sharma, M., \& Gupta, S. (2011). Role of Subjective Norm in Investment Decision Making of Casual Investors. Indian Journal of Finance, 39-46.

25. Suresh, \& Naidu. (2016). An empirical study on announcement effect of the right issue on share price volatility and liquidity and its impact on market wealth creation of informed investors in Bangalore with special reference to CNX nifty stocks of NSE. Retrieved from http://zenithresearch.org.in/.

26. White, \& Lusztig. (1980). The price effects of rights offerings.

27. Journal of finance and quantitative analysis, 25-40. 